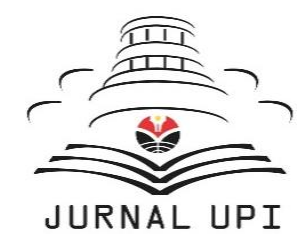

INDONESIAN JOURNAL OF APPLIED LINGUISTICS

Vol. 10 No. 2, September 2020, pp. 304-314

Available online at:

https://ejournal.upi.edu/index.php/IJAL/article/view/28593

https://doi.org/10.17509/ijal.v10i2.28593

\title{
Rhetorical styles of Introduction in English language teaching (ELT) research articles
}

\author{
Anis Firdatul Rochma*, Anita Triastuti, and Ashadi \\ Language Education Science, Graduate School, Universitas Negeri Yogyakarta, Jl. Colombo No 1, \\ Karangmalang, Depok, Sleman, Yogyakarta, 55281, Indonesia
}

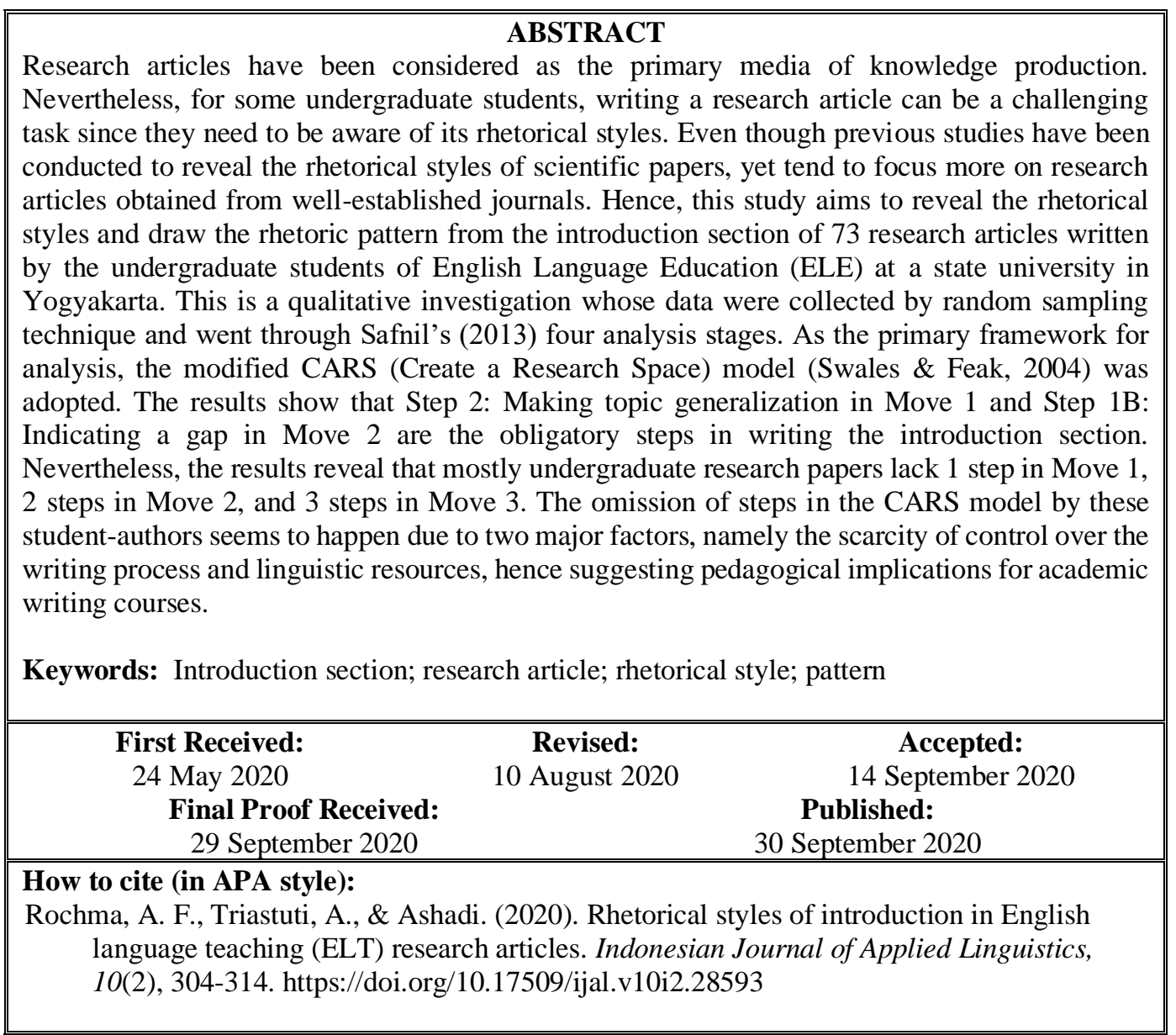

\section{INTRODUCTION}

Interests in the research of rhetorical styles used in writing texts for a specific genre has been growing lately, from persuasive essays (Cahyono, 2000), newspaper editorials (Ansary \& Babaii, 2009), narrative texts (Anas et al., 2016), and humor (Heidari-Shahreza, 2017). The interest also includes the rhetorical styles' analysis of research articles. Some studies have been conducted to analyze those of research papers within several subjects, including medical science (Nwogu, 1997), computer science (Posteguillo, 1999), biochemistry (Kanoksilapatham, 2005), chemistry (Stoller \& Robinson, 2013), and law (Tesutto, 2015). Those studies display the fact that it is necessary to notice and examine the rhetorical styles of scholarly articles since it is considered as a written result of conducting a certain experimental method along with the process of associating the findings with the theory. Thus, those papers need to be written in a proper rhetorical style so that the importance of key issues can be introduced with clarity to the readers.

\section{The concept of rhetoric}

The theory of rhetoric portrays small-scale units, socalled moves, to discover substantial spoken or

\footnotetext{
* Corresponding Author

Email: anisfirdatul.2019@student.uny.ac.id
} 
written arguments from a particular topic (Fahnestock, 2011). Rhetoric is also presented as the effective expressions concerning with selecting an appropriate strategy to create an immediate impression on the readers. The selected strategy involves the process of choosing relevant vocabulary and sentence construction (Levin, 1966). The theory of rhetoric is also regarded as a means of persuasion presenting the facts and significance in a particular discipline (Aristotle, 460/2004). Similarly, the idea of rhetoric can be associated with a method for language analysis involving the process of choosing appropriate lexicon and syntax to create an impression for the readers.

\section{Rhetorical styles of the Introduction section}

To some extent, a style is considered to be a portrayal of the strategy employed by writers in formulating and accomplishing their purposes (Levin, 1966). While the purpose here is associated with cause and effect. From the authors' perspectives, a style is controlled by their choices in writing particular issues from any discipline. Meanwhile, from the readers' perspectives, a style helps them to reveal the intended goal of the writers (McCrimmon, 1973). In specific, the term style helps to determine what the writers are going to do and how they are going to do it.

The concept of rhetorical styles is often employed to describe a systematic variation within a particular genre of texts. Every piece of writing has a different style based on three perspectives; individual writers, historical periods, and text genres (Biber \& Conrad, 2016). From the perspective of individual writers, the rhetorical style is used to portray the writing strategies implemented by different authors. On the other hand, the rhetorical style from the perspective of historical periods is usually used to display the writing strategies employed in a particular period. Meanwhile, from the view of text genres, this rhetorical expression is occupied to illustrate distinctive written organizations of any text genres. In other words, the rhetorical styles employed within a text are needed to describe unique characteristics of various authors, different periods, and diverse genres to reflect individual aesthetic preferences.

One particular type of literary work that has a specific rhetorical style is research-based articles. Thus, in writing this kind of scientific papers, the authors are expected to possess several capabilities, such as writing the research ideas coherently, portraying the research ideas logically, and showing the writer's expertise in the research area (Kumar, 2011). Those competences are inevitably required to notice the distinctive aspects between research articles and other writing works.

A research article is usually written in four sections including introduction, method, results, and discussion (Swales, 1990). Each section contributes to convincing the readers that the research issue is substantial and reliable. Since each section has different and specific objectives, it also maintains its textual organization. Prior studies have been conducted to analyze the textual organization of each sections revealing their rhetorical styles, such as the analysis of the introduction (Hirano, 2009; Loi \& Evans, 2010; Mirahayuni, 2001; Rakhmawati, 2013; Safnil, 2013; Sheldon, 2011), method (Bruce, 2008; Peacock, 2011), results (Basturkmen, 2009; Bruce, 2008), and discussion section (Holmes, 1997; Peacock, 2002). Nevertheless, it seems like the analysis of the introduction section tends to attract most of the authors to broad areas, such as applied sciences (Del Saz-Rubio, 2011; Graves et al., 2014; Kanoksilapatham, 2008; Shehzad, 2008) and social sciences (Loi et al., 2015; Loi \& Evans, 2010; Sheldon, 2011).

The introduction section of research papers generally functions to present the logical explanation of the research and persuade the readers to read the article thoroughly (Swales \& Feak, 2004). Moreover, this section is considered as the most crucial segment due to several reasons. Firstly, it is the first section read by the readers. Secondly, it specifically describes the central idea of the article. Thirdly, it succinctly adds an explanation to the previous study in specific disciplines (Safnil, 2001). Also, this part of the paper is supposed to point out the analysis and significance provided by the current research towards the advancement of human knowledge (Kendal, 2015). Since the essential issues are presented in the introduction section, it is necessary to develop the section by following particular rhetorical styles.

One well-known rhetorical style for the introduction section is the problem-solution text suggested by Toulmin (1972). It was then adopted and developed by Zappen (1983). The problemsolution text consists of five sub-sections, namely goal, current capacity, problem, solution, and criteria of evaluation. However, Swales (1990) declares that the five sub-sections labeling is rather flat and objective, and later proposes another rhetorical style for this section called the Create a Research Space (CARS) model (1990). The projected model was then modified by Swales \& Feak (2004) providing even more direct moves and steps to be occupied.

Since then, rhetorical styles employed in the introduction section have grown to be an interest among researchers from several majors, such as applied linguistics (Hirano, 2009; Rahman et al., 2017), computing (Soler-Monreal, 2011), educational research (Zhang \& Wannaruk, 2016), and medical research (Nwogu, 1997). Several studies have been carried out in Indonesia to explore rhetorical styles commonly used by Indonesian writers (Mirahayuni, 2001; Rakhmawati, 2013; Safnil, 2013). The primary frameworks for most of those studies are either the Create a Research Space (CARS) suggested by Swales (1990) or the modified CARS model by Swales \& Feak (2004) comprising three moves and several steps. 
Those studies indicate that the majority of researchers tend to carry out a study regarding rhetorical styles in the introduction section. However, they are likely to focus on papers issued on wellestablished journals of a particular academic field as the main resources of data. Thus, very little attention has been paid to the very early stage of English academic writing and publication referring to the work of students at the undergraduate level (Swales, 1990). Additionally, it remains unclear whether exposure to English rhetoric as a direct consequence of learning English is a guarantee of a successful manifestation in rhetoric. This concern calls for a further investigation to examine how the English Department students manifest their rhetoric in the introduction section and provide sound arguments that can reason them out.

Hence, this study aims to analyze the rhetorical styles used in the introduction section of research articles following the modified CARS model developed by Swales \& Feak (2004). The modified CARS model is selected as the main framework as it offers clearer moves and steps to properly build the work in the existing body of research and attract the readers (Swales \& Feak, 2004). Research papers written by the undergraduate students of English Language Education (ELE) at a state university om Yogyakarta were collected as the corpus data of this study. A qualitative method was harnessed in the stages of data collection and analysis. To achieve its aim, this study would focus on answering the following research questions.

1. What are the moves and steps of the modified CARS model used by the undergraduate students of ELE in writing the introduction section of their research articles?

2. What pattern is revealed from the rhetorical styles employed by the bachelor students of ELE in writing the introduction section of their research articles?
Therefore, an analysis concerning the rhetorical styles utilized by the undergraduate ELE students at the respective university in writing the introduction section of their scholarly papers was carried out in this study. The analysis was limited to critically evaluating the moves and steps of the modified CARS model (Swales \& Feak, 2004) and justifying the importance of the research topic. In addition, the data analysis would shed light on the revelation of a rhetoric pattern as a means to portray the obligatory and optional moves and steps in the respective section.

\section{METHOD \\ Research design}

An analysis of rhetorical styles manifested in the introduction section of the selected research articles was conducted. The research articles written by the undergraduate students of ELE at a state university in Yogyakarta, Indonesia were previously gathered as the corpus data. These data were then analyzed to establish the rhetorical styles' pattern. Thus, the final reports included both the description and the pattern of moves and steps from the modified CARS model (Swales \& Feak, 2004) employed in the corpus data. Henceforth, considering the above description and explanation, this research is referred to as qualitative.

\section{Research instruments}

The researchers acted as the main instruments of the present study by making the main contribution in collecting, categorizing, analyzing, and interpreting the data as well as inferring the results of the study and drawing the rhetoric pattern. A data sheet was also used in this study to classify the data based on the number of occurrences of the moves and steps. Both of these prominent elements follow the modified CARS model, see Table 1, developed by Swales and Feak (2004). Additionally, the data sheet was utilized to reveal the pattern of the rhetorical styles appearing in the corpus data.

Table 1

The Modified CARS Model by Swales and Feak (2004)

\begin{tabular}{cl} 
MOVE 1 & Step 1: Claiming centrality \\
ESTABLISHING A TERRITORY & Step 2: Making topic generalization \\
& Step 3: Reviewing items of previous research \\
\hline & Step 1A: Counter-claiming (something is wrong) \\
MOVE 2 & Step 1B: Indicating a gap ( something is missing) \\
ESTABLISHING A NICHE & Step 1C: Question-raising (something is unclear) \\
& Step 1D: Continuing a tradition (adding something) \\
& Step 1: Outlining purpose/stating the nature of present research \\
MOVE 3 & Step 2: Listing research questions or hypotheses \\
OCCUPYING THE NICHE & Step 3: Announcing principal findings \\
& Step 4: Stating the value of the present research \\
& Step 5: Indicating the structure of research paper \\
\hline
\end{tabular}

\section{Data collection}

As many as 73 research articles from the English Language Teaching Journal were compiled. The
English Language Teaching Journal launched in 2012 has its goal to promote research and practices on the latest issues concerning ELT in Indonesia. It is 
also interested in the standard and latest theories in Teaching English as a Foreign Language (TEFL). The journal issues can be accessed online on its website. A purposive sampling technique was carried out to select several research papers as the corpus data. A set of particular criteria was previously established as a guideline for accurately selecting the available academic articles. Firstly, the selected research articles should focus on the topic of English Language Teaching. Secondly, they were available in the English Language Teaching Journal of a university in Yogyakarta. Thirdly, the journal articles could be accessed online on the journal website.

\section{Data analysis}

The 73 research articles that met the selection criteria as the corpus data of the study were original and empirical research papers drawn from under the category of English Language Teaching. Most of them were written based on the students' bachelor thesis. Thus, great attention could be given to English academic writing and publication, referring to the work of students at the undergraduate level. The modified CARS model developed by Swales \& Feak (2004) was chosen as the main framework for analyzing the corpus data. The data analysis was carried out to observe the rhetorical styles of the introduction section. The corpus data were analyzed by using the procedures proposed by Safnil (2013), as they were divided into the four analysis stages.

The first stage focused on carefully reading the paper's titles, abstracts, and key terms to get an initial understanding of the research topic. The second stage centered on identifying the frequent appearances of the moves and steps of the modified CARS model. The third stage was centralized at identifying the linguistic features and discourse clues, such as the specific lexical items, formulaic expressions, and cohesive markers. The last stage concentrated on drawing a concluson and rhetoric pattern to get a better frame related to the communicative purpose of the introduction section.

\section{Data trustworthiness}

The data trustworthiness was established through the content validity and expert judgment. The content validity was assured by straightforwardly defining the research objective that is going to be examined (Brown, 2004). This was carried out through the process of analyzing and referring the corpus data to the primary framework. As a result, the identification of moves and steps based on the modified CARS model (Swales \& Feak, 2004) was conducted. Above all, expert judgment was also adequately utilized. It was a fundamental part of making judgments towards the compatibility between the theoretical framework and the corpus data. The expert involved as a reviewer and validator in the present study is a lecturer of the English Language Education Department at a state university in Yogyakarta who has a profound understanding of rhetorical styles in writing the introduction section of scientific articles.

\section{FINDINGS AND DISCUSSION \\ Moves and steps of the CARS model}

The CARS (Create a Research Space) model of the introduction section (Swales, 1990; Swales \& Feak, 2004) consists of three moves and several steps. Some of the essential steps are obligatory, and the others are optional (Swales, 1990). The introduction section in research articles essentially functions to present the logical explanation of the research and persuade the readers to read the articles thoroughly (Swales \& Feak, 2004). Thus, it is necessary to discuss the relevant literature and portray the originality of the study in this section (Swales, 1990).

The frequencies of moves and steps in the corpus data are displayed in Table 2. Both elements correspond to the modified CARS model (Swales \& Feak, 2004). Following Kanoksilapatham (2005), this study determines that the cut-off frequency is $60 \%$. That is to say, if a move or step appears $60 \%$ or above, it can be regarded as an obligatory move or step.

However, if a move or step appears less than $60 \%$, it is optional (Kanoksilapatham, 2005). It is apparent in Table 2 that the frequency of making topic generalization from Move 1 is $84 \%$, and that of indicating a gap from Move 2 is $85.3 \%$. Hence, making topic generalization and indicating a gap can be viewed as obligatory steps.

\section{Move 1: Establishing a territory}

Following Rahman et al. (2017), the introduction section in this study begins with Move 1 . However, the steps found may not be put into operation (Rahman et al., 2017).

\section{Step 1: Claiming centrality}

Claiming centrality is one of the steps in Move 1 usually employed to ask for the readers' acceptance as the research article is believed to contribute to the well-established research field. This can be implemented through three strategies, namely referring to; (1) classic works, (2) fundamental character of the research issue, and (3) the active issues investigated by other experts (Swales, 1990). As seen in Table 2, claiming centrality appears 12 times in the corpus data. Since its presence occurs less than $60 \%$, claiming centrality can be considered as an optional step in Move 1.

\section{Step 2: Making topic generalization}

Creating topic generalization usually seeks to show a particular research topic generalization. Making topic generalization can be operationalized by involving a clear statement of research knowledge or practice as well as that of the research phenomenon (Swales, 1990). As stated in Table 2, making topic 
generalization occurs 63 times in the corpus data. Since it appears in more than $60 \%$ of the scientific papers, making topic generalization can be considered as an obligatory step in Move 1. The manifestations of making topic generalization are described in the following examples.

\# The rapid development of the world is also followed by the development in the educational field especially in English teaching and learning since English is widely used as an international language (Article 11, Vol. 7 No. 2).
\#In English Language Teaching, interaction is used to indicate the language (or action) used to maintain conversation, teach or interact with participants involved in teaching and learning in the classroom (Article 13, Vol. 7 No. 2).

\#Motivation and independence are two of many important factors influencing students' learning habits that nowadays often get underrated (Article 59, Vol. 7 No. 6).

Table 2

Moves and Steps of the CARS Model Employed in the Corpus Data

\begin{tabular}{|c|c|c|c|}
\hline $\begin{array}{c}\text { Moves_Steps_Number } \\
\text { of Occurrences }\end{array}$ & $\%$ & & \\
\hline Move 1: & Claiming centrality & 12 & 16 \\
\hline \multirow{3}{*}{$\begin{array}{c}\text { Establishing a } \\
\text { territory }\end{array}$} & Making topic generalization & 63 & 84 \\
\hline & Reviewing items of previous research & 0 & 0 \\
\hline & Counter-claiming & 0 & 0 \\
\hline \multirow{3}{*}{$\begin{array}{c}\text { Move 2: } \\
\text { Establishing a niche }\end{array}$} & Indicating a gap & 64 & 85.3 \\
\hline & Question-raising & 0 & 0 \\
\hline & Continuing a tradition & 4 & 5.3 \\
\hline \multirow{5}{*}{$\begin{array}{c}\text { Move 3: } \\
\text { Occupying the niche }\end{array}$} & Outlining purpose/ stating the nature of present research & 40 & 53.3 \\
\hline & Listing research questions or hypotheses & 13 & 17.3 \\
\hline & Announcing principal findings & 0 & 0 \\
\hline & Stating the value of the present research & 0 & 0 \\
\hline & Indicating the structure of research paper & 0 & 0 \\
\hline
\end{tabular}

As seen in Table 2, not all steps in Move 1 appear in the corpus data since Step 3 - Reviewing items of previous research is omitted. This finding contradicts Rahman's et al. (2017), asserting that Step 3 in Move 1 is highly used in the applied linguistics research papers, including those discussing English Language Teaching and English for Specific Purposes. Nevertheless, the finding of the present research is in line with Suryani et al. (2013), who argue that Step 2 of Move 1 is highly utilized to begin the introduction section with a general statement followed by a more specific research topic. Another similar finding to Suryani's et al. (2013) lies in the corpus data in which the writers' first language (L1) is not English. On the contrary, the corpus data of Rahman et al. (2017) are written by native speakers of English. The differences may occur, probably, because English native speakers tend to employ a direct thesis statement by providing specifications of prior findings, attributions to writers, and taking a stance by deciding their position (Swales, 1990). Meanwhile, non-native speakers of English seem to have a strong tendency to portray topic generalization emphasized by the complexity of data.

\section{Move 2: Establishing a niche}

Move 2 of the CARS model is identified as a minicritique (Swales \& Feak, 2004) since its goal is to relate prior studies with the current ones and to encourage particular disciplines to move forward
(Shehzad, 2008). In the Swales' CARS model (1990, 2004), Move 2 is a strategy in which the writers are expected to justify the research space. Hence, the primary role of Move 2 is to portray the existing weaknesses and present a convincing argument, showing the gaps inparticular research.

\section{Step 1B: Indicating a gap}

Indicating a gap refers to the step allowing the writers to highlight the disparity of the existing research that put up with some limitations (Swales, 1990). It can be clearly noticed in Table 2 that indicating a gap occurs 64 times in the corpus data. Since its appearance counts more than $60 \%$, indicating a gap can be considered as an obligatory step in Move 2. The examples of sentences used for indicating a gap are presented below.

\#However, there are hardly English learning materials which are developed for specific study programs in Vocational High School in Indonesia (Article 9, Vol. 7 No. 2).

\#There are still many problems with the use of technology in teaching English in Indonesia (Article 11, Vol. 7 No. 2).

\#However, politeness in everyday notion is different from politeness in the research (Article 49, Vol. 7 No. $5)$

\section{Step 1D: Continuing a tradition}

Continuing a tradition allows the writers to justify the significant value of their research. By extending the 
prior research results, it builds up the existing theory of particular disciplines (Swales, 1990). In most cases, it is noticed through the use of connecting markers, such as henceforth, therefore, in consequence, and as a result. As seen in Table 2, continuing a tradition appears four times in the corpus data. Since its presence occurs less than $60 \%$, continuing a tradition can be regarded as optional in Move 2.

In the present study, indicating a gap in Move 2 is a step with the highest percentage. Such research finding is in line with prior studies of Kanoksilapatham (2011), Pho (2008), Rahman et al. (2017), Samraj (2002), and Saz-Rubio (2011). These investigations assert that such lexically signaled verbs as lacking and very little research exists are frequently employed in this step. Similarly, the present study also discloses several lexically signaled verbs, such as limited resources, difficulties, quite hard, not always available, low, and failure. These can be used to show that the writers 'suffer from limitation' (Swales, 1990, p.154). Thus, based on the findings of this study and prior studies, Move 2 is realized mainly by indicating a gap through the use of lexically signaled verbs.

\section{Move 3: Occupying the niche}

Move 3 of the CARS model is responsible for proposing further actions with due regard to the importance mentioned above of the research topic portrayed in Move 1 and 2 (Swales \& Feak, 2004). It elucidates the fact that the rhetorical flow in Move 1 is closely linked with that of Move 2 and 3 . Moreover, Move 3 is expected to fulfill several goals, namely to (1) affirm the well-established counterclaiming, (2) fulfill the research gap, (3) react to precise questions, and (4) carry on the conclusively proved tradition (Swales, 1990).

Step 1A: Outlining purpose/stating the nature of present research

In this study, as realized in Table 2, outlining purpose appears 40 times in the corpus data. Thus, it can be said that outlining purpose is a highly used step in Move 3. This finding is in line with the prior theory stating that the introduction section usually wraps up with Step 1, which is outlining purpose (Swales, 1990). However, outlining purpose is considered as non-mandatory in Move 3 since it occurs in less than $60 \%$ papers. The sample expressions for outlining purpose are given below:

\# This research focuses on using the Task-Based Language Teaching approach to develop the supplementary materials (Article 27, Vol. 7 No. 3).

\# The research conducted was aiming to discover the target and learning needs of young learners in starting English school, and to design a set of quartet cards to aid the learners in learning English preposition (Article 48, Vol. 7 No. 5).
\# This research proposes to develop an educational reading video game for Grade $\mathrm{X}$ students of the Senior High School (Article 51, Vol. 7 No. 6).

Step 1B: Listing research questions or hypotheses In this study, listing research questions or hypotheses occurs 13 times in the corpus data. The examples of this are presented in the following excerpts.

\# The problems of this research are formulated as follows: (1) What are the needs of the third-grade students of elementary schools in learning English? (2) What are the appropriate story-based English learning materials for the third-grade students of elementary schools like? (Article 6, Vol. 7 No. 1).

\# The formulation of the problems of this research are: (1) What are the target and learning needs of English Specific Purposes of young learners group B in learning vocabulary? (2) What do the appropriate theme-based English vocabulary learning materials for young learners group B in kindergartens look like? (Article 17, Vol. 7 No. 2).

\begin{abstract}
\# Based on the previous explanation, this research aims to answer the questions on: (1) What are the target and learning needs of learning speaking of grade VIII junior high school? (2) How is an appropriate board game to teach speaking for grade VIII junior high school students developed? (Article 22, Vol. 7 No. 3 )
\end{abstract}

Table 2 indicates that outlining purpose is the most frequently used step in Move 3. This finding resembles the results of prior studies conducted by Jalilifar (2010), Jogthong (2001), and Rahman et al. (2017). The fact that outlining purpose counts the highest among other steps in Move 3 demonstrates the notion that it is an essential step for the actualization of Move 3. Although it is the most frequently used step, yet outlining purpose is considered as optional since it occurs less than $60 \%$.

Additionally, it can be recognized that the corpus data utilize two out of five steps in Move 3. This finding contradicts Sheldon (2011) and Rahman et al. (2017) who state that authors of research papers utilized all the steps in Move 3. The dissimilarity of these findings is perhaps due to the total corpus-based resources as it would be possible to find all the steps in Move 3 with a larger corpus. Besides, the dissimilarity may occur since the corpus for these studies is selected from different L1. The corpus data of Sheldon (2011) and Rahman et al. (2017) were written by the speakers whose L1 is English. Meanwhile, those used in this study were written by learners of English as a foreign language.

\section{Patterns of rhetorical styles}

The findings of this study indicate that the rhetorical style of the corpus data complies with the modified CARS model developed by Swales \& Feak (2004). The three moves of the CARS model likely appear in the corpus data of this study. Besides, Step 2 in Move 1 and Step 1B in Move 2 appear to be obligatory ones. 
Nevertheless, the steps employed in the corpus data also depart from the CARS model. Move 1 of the CARS model consists of three steps, but there are only two steps employed in the corpus data. Moreover, there are only two steps of Move 2 employed in the corpus data even though there exist four steps in Move 2 in the modified CARS model. Additionally, only two steps of Move 3 occur in the corpus data, while there are five steps proposed in the modified CARS model. Thus, it may imply that several steps are not present in the corpus data of the present study. The omitted steps are Step 3: Reviewing items of previous topic from Move 1, Step 1A: Counter-Claiming, Step 1C: Question-raising from Move 2, Step 3: Announcing principal findings, Step 4: Stating the value of the present research, and Step 5: Indicating the structure of research paper from Move 3. The pattern of move structure in the corpus data can be seen in Table 3 .

Table 3

Patterns of Move Structure

\begin{tabular}{|c|c|c|c|}
\hline $\begin{array}{c}\text { Research Articles_Moves' } \\
\text { Occurrences }\end{array}$ & Research Articles & Moves' Occurrences & \\
\hline ELT-1 / Volume 7 (1) & $1-2-3$ & ELT-8 / Volume 7 (4) & $1-3$ \\
\hline ELT-2 / Volume 7 (1) & $1-2-3$ & ELT-9 / Volume 7 (4) & $1-2-3$ \\
\hline ELT-3 / Volume 7 (1) & $1-2-3-3$ & ELT-10 / Volume 7 (4) & $1-2-3$ \\
\hline ELT-4 / Volume 7 (1) & $1-2$ & ELT-1 / Volume 7 (5) & $1-2-3$ \\
\hline ELT-5 / Volume 7 (1) & $1-2$ & ELT-2 / Volume 7 (5) & $1-2-3$ \\
\hline ELT-6 / Volume 7 (1) & $1-2$ & ELT-3 / Volume 7 (5) & 1 \\
\hline ELT-7 / Volume 7 (1) & $1-2$ & ELT-4 / Volume 7 (5) & $1-2-3$ \\
\hline ELT-8 / Volume 7 (1) & $1-2-3$ & ELT-5 / Volume 7 (5) & $1-2-3$ \\
\hline ELT-9 / Volume 7 (1) & $1-2-3$ & ELT-6 / Volume 7 (5) & $1-2-3$ \\
\hline ELT-10 / Volume 7 (1) & $1-2-3$ & ELT-7 / Volume 7 (5) & $1-2-3$ \\
\hline ELT-1 / Volume 7 (2) & $1-2-3$ & ELT-8 / Volume 7 (5) & $1-2-3$ \\
\hline ELT-2 / Volume 7 (2) & $1-2-3$ & ELT-9 / Volume 7 (5) & $1-2$ \\
\hline ELT-3 / Volume 7 (2) & $1-2$ & ELT-10 / Volume 7 (5) & $1-2-3$ \\
\hline ELT-4 / Volume 7 (2) & $1-2$ & ELT-1 / Volume 7 (6) & $1-2-3$ \\
\hline ELT-5 / Volume 7 (2) & 1 & ELT-2 / Volume 7 (6) & $1-2-3$ \\
\hline ELT-6 / Volume 7 (2) & $1-2$ & ELT-3 / Volume 7 (6) & $1-2-3$ \\
\hline ELT-7 / Volume 7 (2) & $1-3$ & ELT-4 / Volume 7 (6) & $1-2$ \\
\hline ELT-8 / Volume 7 (2) & $1-2-2-3$ & ELT-5 / Volume 7 (6) & $1-3$ \\
\hline ELT-9 / Volume 7 (2) & $1-2-3$ & ELT-6 / Volume 7 (6) & $1-3$ \\
\hline ELT-10 / Volume 7 (2) & $1-2-3$ & ELT-7 / Volume 7 (6) & $1-2$ \\
\hline ELT-1 / Volume 7 (3) & $1-2$ & ELT-8 / Volume 7 (6) & $1-2-3$ \\
\hline ELT-2 / Volume 7 (3) & $1-2$ & ELT-9 / Volume 7 (6) & $1-2-3$ \\
\hline ELT-3 / Volume 7 (3) & $1-2-3$ & ELT-10 / Volume 7 (6) & $1-2-3$ \\
\hline ELT-4 / Volume 7 (3) & $1-2$ & ELT-1 / Volume 7 (7) & $1-2$ \\
\hline ELT-5 / Volume 7 (3) & $1-2$ & ELT-2 / Volume 7 (7) & $1-2-3$ \\
\hline ELT-6 / Volume 7 (3) & $1-2$ & ELT-3 / Volume 7 (7) & $1-2$ \\
\hline ELT-7 / Volume 7 (3) & $1-2-3$ & ELT-4 / Volume 7 (7) & $1-2-3$ \\
\hline ELT-8 / Volume 7 (3) & $1-2-3$ & ELT-5 / Volume 7 (7) & $1-2-3$ \\
\hline ELT-9 / Volume 7 (3) & $1-2-3$ & ELT-6 / Volume 7 (7) & $1-3$ \\
\hline ELT-10 / Volume 7 (3) & $1-2$ & ELT-7 / Volume 7 (7) & $1-2-3$ \\
\hline ELT-1 / Volume 7 (4) & $1-2$ & ELT-8 / Volume 7 (7) & $1-2-3$ \\
\hline ELT-2 / Volume 7 (4) & $1-2$ & ELT-9 / Volume 7 (7) & $1-2-3$ \\
\hline ELT-3 / Volume 7 (4) & $1-2-3$ & & \\
\hline ELT-4 / Volume 7 (4) & $1-2-3$ & ELT-1 / Volume 7 (8) & $1-2-3$ \\
\hline ELT-5 / Volume 7 (4) & $1-2$ & ELT-2 / Volume 7 (8) & $1-2-3$ \\
\hline ELT-6 / Volume 7 (4) & $1-2$ & ELT-3 / Volume 7 (8) & $1-2$ \\
\hline ELT-7 / Volume 7 (4) & $1-2-3$ & ELT-4 / Volume 7 (8) & $1-2-3$ \\
\hline
\end{tabular}

The findings of the present study lead to the revelation of a rhetoric pattern, as illustrated in Table 4. It can be seen that there are two obligatory steps employed in the corpus data. The first obligatory step is Step 2: Making topic generalization from Move 1. The corpus data in this study tend to express general issues in establishing a territory. It is followed by displaying the frequency and complexity of the phenomena. The fact that Step 2 of Move 1 becomes the obligatory step in this study contradicts Swales \& Feak (2004), stating that the obligatory step of Move 1 is Step 3: Reviewing items of previous research.
They also propose several motives of reviewing items of previous research; including to (1) acknowledge the intellectual property of previous writers, (2) show respect for earlier writers, (3) give more authority in the arguments, (4) promote colleagues, and (5) to be included in a particular disciplinary community (Swales \& Feak, 2004). In other words, according to Swales \& Feak (2004), Step 3 is obligatory in Move 1 since it provides a direct thesis statement by portraying what has been claimed and who has claimed it. However, it is noteworthy to report that the corpus data in this study seem to cite and review 
previous research after presenting the general phenomena. The citing of previous research is often used to show the rarity of the phenomena (Swales, 1990). Alternatively stated, the writers cite and review previous research studies not to present direct thesis statements straightforwardly; instead, it is used to show the readers that there is a uniqueness of particular phenomena.

Table 4

The Pattern of Rhetorical Styles

\begin{tabular}{c} 
Move 1: Establishing a territory \\
S1: Claiming centrality (optional) \\
S2: Making topic generalization (obligatory) \\
\hline Move 2: Establishing a niche \\
S1B: Indicating a gap (obligatory) \\
S2: Continuing a tradition (optional) \\
Move 3: Occupying the niche \\
S1: Outlining purpose/Stating the Nature of Present \\
Research (optional) \\
S2: Listing the research questions or hypotheses \\
(optional)
\end{tabular}

The second obligatory step is Step 1B: Indicating a gap from Move 2. This finding corresponds with the previous theory suggested by Swales \& Feak (2004), that Step 1B in Move 2 can directly exhibit the indications of gaps to establish a niche.

One particular strategy to indicate the gaps is by using lexically signaled verbs. The negative quantifiers, lexical negation, and negation in the verb phrase can be utilized to indicate the gaps (Swales, 1990). In this study, lexical negation and negation in the verb phrase are more frequently used in the corpus data rather than negative quantifiers. This finding is similar to previous studies (Kanoksilapatham, 2011; Pho 2008; Rahman et al., 2017; Samraj, 2002; Saz-Rubio, 2011;) in which the lexical negation and negation in the verb phrase are mostly used in the corpus data. This similarity occurs, probably, because the writers of the corpus data tend to suggest self-approval, attribute to particular vision confinement, or provide a narrow description of prior studies (Swales, 1990) rather than focusing on the preferred choice of works.

Additionally, as stated in Table 4, there is no obligatory step in Move 3 in the present study. It contradicts prior studies (Swales \& Feak, 2004; Rahman et al., 2017) that assert that Step 1: Outlining purpose of Move 3 is considered as an obligatory step in the modified CARS model. Nevertheless, the findings of this study indicate that outlining purpose is the most frequently used step in Move 3 although it is not considered as mandatory.

Furthermore, as seen in Table 3, several research articles selected in the corpus data omit Move 3 in the introduction section. That is to say, some of the corpus data in this study exclude the process of filling the gaps and proposing further actions by omitting Move 3 .
Another important finding from the present study is the use of indirect statements to introduce the research topic. In other words, the research topic tends to be delayed. This seems to display the circular approach (Kaplan, 1966) in which the introduction section is developed without directly emphasizing the subject. The present finding corresponds to the previous study conducted by Mirahayuni (2001). Her research proclaims that Indonesian writers tend to delay the topic introduction.

The fact that the corpus data in this study eliminate several steps suggested by the modified CARS model seems to happen due to two significant factors, the scarcity of control over the writing process and that of linguistic resources available to recognize the stages of writing (Mirahayuni, 2001). Those two factors appear to be the significant factors determining the styles employed by the Indonesian writers in writing the introduction section of their research-based journal articles.

This study has revealed that the papers utilize linking markers to portray the relationships among sentences, such as however, in contrast, in this regard, and moreover. This finding is in line with the previous study conducted by Safnil (2001), that the introduction sections written by Indonesian writers often use linking markers. Hence, it shows the capability of Indonesian writers to build a semantic meaning within sentences. Furthermore, Tanskanen (2006) supports that the use of linking markers or cohesive devices signifies the coherence of the text. Then, it can be assumed that linking markers can be one of the features of text coherence. Henceforth, it is noteworthy to state that most of the introduction sections in the corpus data were written coherently.

\section{Pedagogical implication}

The proposed rhetoric pattern in this study can be a manifestation of how the undergraduate students of ELE organize the introduction section of their research articles. In this light, prior research claims that rhetorical styles of particular genres are worth exploring in the English as Academic Purposes (EAP) class (Loi et al., 2015). It is also essential to introduce the concept of rhetorical styles in the academic writing class as an effort to assist them in writing a specific genre (Khansari et al., 2016), especially research articles.

In writing the introduction section, the CARS model by Swales \& Feak (2004) can be one of the eminent rhetorical styles to be included in the English writing classes. The students can choose toeither announce the primary point or introduce the sources to establish a territory in the introduction section. In other words, they can use claiming centrality, making topic generalization, or reviewing items of previous research, as stated in Move 1 of the CARS model (Swales \& Feak, 2004). Besides, the students can examine any facts, concrete evidence, theories, and beliefs concerning the research issue. By examining 
them, the students may relate the prior facts with current knowledge.

To show a convincing argument of the research importance, students-authors can apply Move 2 of the CARS model (Swales \& Feak, 2004). They can establish a niche by indicating a gap, raising a question, continuing a tradition, and counterclaiming. Additionally, they can formulate a thesis statement after occupying the niche through outlining purpose, listing hypotheses, announcing principal findings, stating the research value, or indicating the structure of research paper, as stated in Move 3 of the Swales \& Feak's (2004) CARS model. By doing so, they are likely to strengthen their position on the issue and defend their perspectives (Meyers, 2014).

\section{CONCLUSION}

This study reveals the rhetoric pattern of the undergraduate ELE students in writing the introduction section of their research articles. The proposed rhetoric pattern as seen in the corpus data can be a manifestation of how these students construct and organize the section. In other words, the suggested pattern may provide more understanding of rhetorical styles in research papers written by the bachelor students of ELE. Likewise, it may contribute to show the fact that there is an essential need to introduce the concept and develop the awareness of rhetoric styles to the undergraduate students as an effort to assist them in publishing their research in the ELT field.

The need to introduce rhetorical styles to the students is considered crucial as it may assist them in justifying the research importance. Research on genre-based pedagogy (e.g., Huang \& Zhang, 2020) has confirmed the effectiveness of genre-based instruction to improve students' textual knowledge and skills, including knowledge of rhetorical steps (generic structure) of texts.

Although this study provides beneficial information regarding the rhetorical styles of the introduction section of scholarly papers written by undergraduate students, yet the corpus of this study should be treated with caution. On account of this relatively limited corpus data, future researchers may need to conduct further studies with bigger corpora from several journals to enhance the generalizability of the findings.

\section{REFERENCES}

Anas, M., Ismail, N., Rashid, R., Halim, Z., \& Zubir, B. (2016). The narrative structure and rhetorical elements in the companions of cave. International Journal of Applied Linguistics \& English Literature, 5(5), 70-73. https://doi.org/10.7575/aiac.ijalel.v.5n.5p.70

Ansary, H. \& Babaii, E. (2009). A cross-cultural analysis of English newspaper editorials: a systemic-functional view of text for contrastive rhetoric research. RELC Journal, 40(2), 211249.

https://doi.org/10.1177/0033688209105867

Aristotle. (2004). Rhetoric (R. Roberts, Trans.). Dover Publications. (Original work published ca. 460 BCE)

Basturkmen, H. (2009). Commenting on results in published research articles and masters dissertations in language teaching. Journal English for Academic Purposes, 8(4), 241-251. https://doi.org/10.1016/j.jeap.2009.07.001

Biber, D. \& Conrad, S. (2016). Grammatical complexity in academic English: Linguistic change in writing. Cambridge University Press.

Brown, D. (2004). Language assessment principles and classroom practices. Longman Group Ltd.

Bruce, I. (2008). Cognitive genre structures in methods sections of research articles: A corpus study. Journal of English for Academic Purposes, 7(1), 38-54. https://doi.org/10.1016/j.jeap.2007.12.001

Cahyono, B. (2000). Rhetorical strategies used in Indonesian persuasive essays written by students majoring in Indonesian and in English. K@ta, 2(1), 31-39. https://doi.org/10.9744/kata.2.1.31-39

Del Saz-Rubio, M. (2011). A pragmatic approach to the macro-structure and metadiscoursal features of research article introductions in the field of Agricultural Sciences. English for Specific Purposes, 30(4), 258-271. https://doi.org/10.1016/j.esp.2011.03.002

Fahnestock, J. (2011). Rhetorical style the uses of language in persuasion. Oxford University Press.

Heidari-Shahreza, M. (2017). A rhetorical analysis of humor styles and techniques used in Persian stand-up comedy. HUMOR, 30(4), 359-381. https://doi.org/10.1515/humor-2017-0025

Hirano, E. (2009). Research article introductions in English for specific purposes: A comparison between Brazilian Portuguese and English. English for Specific Purposes, 28, 240-250. https://doi.org/10.1016/j.esp.2009.02.001

Holmes, R. (1997). Genre analysis and the social sciences: An investigation of the structure of research article discussion sections in three disciplines. English for Specific Purposes, 16(4), 321-337. https://doi.org/10.1016/s08894906(96)00038-5

Huang, Y. \& Zhang, L. J. (2020). Does a processgenre approach help improve students' argumentative writing in English as a foreign language? Findings from an intervention study. Reading \& Writing Quarterly, 36(4), 339-364. https://doi.org/10.1080/10573569.2019.164922 3

Jalilifar, A. (2010). Research article introductions: Subdisciplinary variations in applied 
linguistics. The Journal of Teaching Language Skills, 2(2), 29-55.

Jogthong, C. (2001). Research article introductions in Thai: Genre analysis of academic writing [Unpublished doctoral Dissertation]. West Virginia University.

Kanoksilapatham, B. (2005). Rhetorical structure of biochemistry research articles. English for Specific Purposes, 24(3), 269-292. https://doi.org/10.1016/j.esp.2004.08.003

Kanoksilapatham, B. (2011). Civil engineering research article introductions: Textual structure and linguistic characterization. The Asian ESP Journal, 7(2), 55-84.

Kaplan, R. (1966). Cultural thought patterns in intercultural education. Language Learning, 16 (1-2), 1-20.

Kendal, S. (2015). How to write a research paper. Bookboon.

Khansari, D., Heng, C., Yuit, C., \& Tan, H. (2016). Regularities and irregularities in rhetorical move structure of linguistics abstracts in research articles. Language, Linguistics, Literature, 22(1), 39-54. http://doi.org/10.17576/3L-2016-2201-04

Kumar, R. (2011). Research methodology: A stepby-step guide for beginners. Sage Publications Ltd.

Levin, G. (1966). A brief handbook of rhetoric. Harcourt, Brace, and World Inc.

Loi, C. \& Evans, M. (2010). Cultural differences in the organization of research article introductions from the field of educational psychology: English and Chinese. Journal of Pragmatics, 42, 2814-2825. https://doi.org/10.1016/j.pragma.2010.03.010

Loi, C., Evans, M., Akkakoson, S., Ahmed, A., \& Ahmed, S. (2015). Rhetorical patterns in the discussion sections of Malay research articles. International Journal of Languages, Literature, and Linguistics, 1(2), 118-121. https://doi.org/10.7763/IJLLL.2015.V1.23

McCrimmon, J. (1973). Writing with a purpose. Houghton Mifflin Company.

Meyers, A. (2014). Longman academic writing series. Pearson Education.

Mirahayuni, N. (2001). Investigating generic structure of English research article writing strategy differences between English and Indonesian writers. TEFLIN Journal, 13(1), 22-57.

http://dx.doi.org/10.15639/teflinjournal.v13i1/ $22-57$

Nwogu, K. (1997). The medical research paper: Structure and functions. English for Specific Purposes, 16(2), 119-138. https://doi.org/10.1016/S0889-4906(97)853884

Peacock, M. (2002). Communicative moves in the discussion section of research articles. System,
30(4), 479-497. https://doi.org/10.1016/S0346251X(02)00050-7

Peacock, M. (2011). The structure of the methods section in research articles across eight disciplines. Asian ESP Journal, 7(2), 97-124. http://asian-esp-journal.com/wpcontent/uploads/2016/01/AESP-Volume7Issue2-April-2011.pdf

Pho, P. (2008). Research article abstracts in applied linguistics and educational technology: a study of linguistic realizations of rhetorical structure and authorial stance. Discourse Studies, 10(2), 231-250. https://doi.org/10.1177\%2F146144560708701 0

Posteguillo, S. (1999). The schematic structure of computer science research articles. English for Specific Purposes, 18(2), 139-160. https://doi.org/10.1016/S0889-4906(98)000015

Rahman, M., Darus, S., \& Amir, Z. (2017). Rhetorical structure of introduction in applied linguistics research articles. International Journal for Educational Studies, 9(2), 69-84. https://mindamasjournals.com/educare/article/view/800

Rakhmawati, A. (2013). English research article written by Indonesian academics: Coping with common practices and rhetorical diversity. In FLLT 2013 Conference Proceedings (pp. 265275). The Language Institute of Thammasat University. http://litu.tu.ac.th/FLLT2013/www.fllt2013.or $\mathrm{g} /$ private_folder/Proceeding/265.pdf

Safnil. (2001). Rhetorical structure analysis of the Indonesian research articles. [Unpublished doctoral dissertation]. The Australian National University.

Safnil. (2013). A genre-based analysis on the introductions of research article written by Indonesian academics. TEFLIN Journal, 24(2), 180-200.

http://dx.doi.org/10.15639/teflinjournal.v24i2/ 180-200

Samraj, B. (2002). Introduction in research articles: variations across disciplines. English for Specific Purposes, 21(1), 1-17. https://doi.org/10.1016/S0889-4906(00)000235

Shehzad, W. (2008). Move two: Establishing a niche. Ibérica: Revista de la Asociación Europea de Lenguas para Fines Específicos, 15, 25-50. https://www.redalyc.org/articulo.oa?id=28702 4060003

Sheldon, E. (2011). Rhetorical differences in RA introductions written by English L1 and L2 and Castilian Spanish L1 writers. Journal of English for Academic Purposes, 10, 238-251. https://doi.org/10.1016/j.jeap.2011.08.004 
Stoller, F. \& Robinson, M. (2013). Chemistry journal articles: An interdisciplinary approach to move analysis with pedagogical aims. English for Specific Purposes, 32(1), 45-57. https://doi.org/10.1016/j.esp.2012.09.001

Suryani, I., Kamaruddin, H., Hashima, N., Yaacob, A., Rashid, S., \& Desa, H. (2014). Rhetorical structure in academic research writing by nonnative writers. International Journal of Higher Education, 3(1), 29-38. https://doi.org/10.5430/ijhe.v3n1p29

Swales, J. (1990). Genre analysis: English in academic and research settings. Cambridge University Press.

Swales, J.M \& Feak, C.B. (2004). Academic writing for graduate students: Essential tasks and skills. The Michigan University Press. Tanskanen, S-K. (2006). Collaborating towards coherence: Lexical cohesion in English discourse. John Benjamins Publishing Co.
Tessuto, G. (2015). Generic structure and rhetorical moves in English-language empirical law research articles: Sites of interdisciplinary and interdiscursive cross-over. English for Specific Purposes, 37, 13-26. https://doi.org/10.1016/j.esp.2014.06.002

Toulmin, S. (1972, January). Rationality and scientific discovery. In PSA: Proceedings of the Biennial meeting of the philosophy of science association (Vol. 1972, pp. 387-406). D. Reidel Publishing.

Zappen, J. P. (1983). Aristotelian and Ramist Rhetoric in Thomas Hobbes's Leviathan: Pathos versus Ethos and Logos. Rhetorica, 1(1), 65-91. https://doi.org/10.1525/rh.1983.1.1.65

Zhang, B. \& Wannaruk, A. (2016). Rhetorical structure of education research article methods section. International Journal of Languages, Literature and Linguistics, 4(2), 132-136. https://doi.org/10.18178/ij1ll.2018.4.2.162 